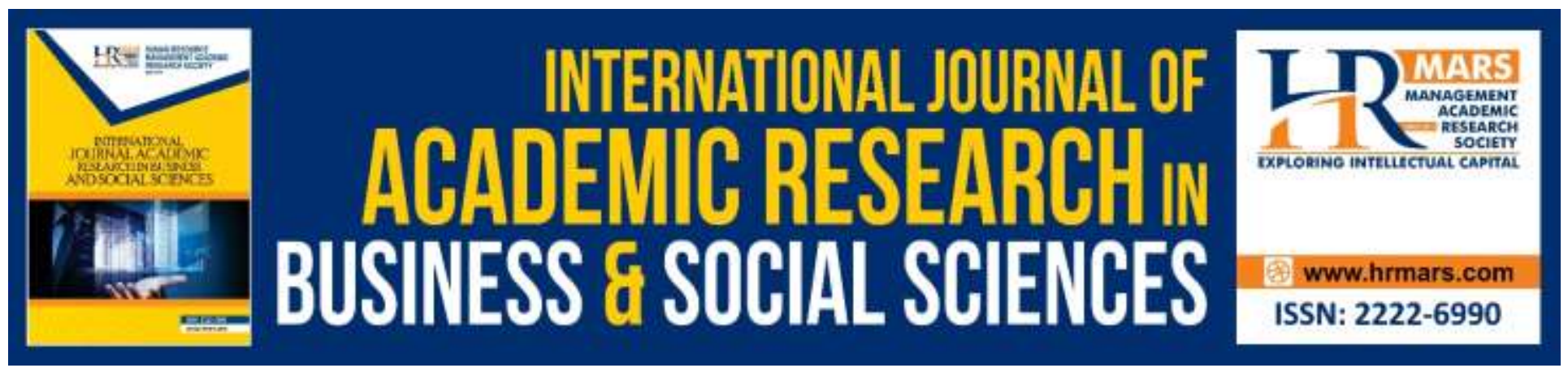

\title{
Interactive Mechanism of Money Supply and Economic Growth: Analysis of the Causal Relationship in Nigeria
}

\section{Miftahu Idris}

To Link this Article: http://dx.doi.org/10.6007/IJARBSS/v9-i7/6120

DOI: $10.6007 /$ IJARBSS/v9-i7/6120

Received: 20 May 2019, Revised: 22 June 2019, Accepted: 03 July 2019

Published Online: 29 July 2019

In-Text Citation: (Idris, 2019)

To Cite this Article: Idris, M. (2019). Interactive Mechanism of Money Supply and Economic Growth: Analysis of the Causal Relationship in Nigeria. International Journal of Academic Research in Business and Social Sciences, 9(7), 324-338.

\section{Copyright: (C) 2019 The Author(s)}

Published by Human Resource Management Academic Research Society (www.hrmars.com)

This article is published under the Creative Commons Attribution (CC BY 4.0) license. Anyone may reproduce, distribute, translate and create derivative works of this article (for both commercial and non-commercial purposes), subject to full attribution to the original publication and authors. The full terms of this license may be seen at: http://creativecommons.org/licences/by/4.0/legalcode

Vol. 9, No. 7, 2019, Pg. 324 - 338

Full Terms \& Conditions of access and use can be found at http://hrmars.com/index.php/pages/detail/publication-ethics 


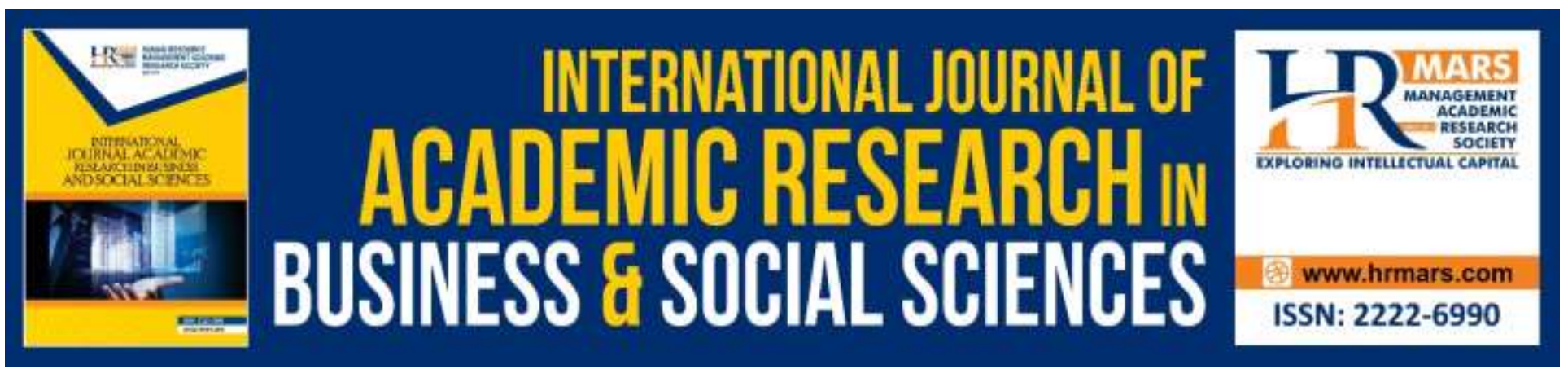

\title{
Interactive Mechanism of Money Supply and Economic Growth: Analysis of the Causal Relationship in Nigeria
}

\author{
Miftahu Idris \\ Department of Economics, Taraba State University Jalingo, Nigeria \\ Email: miftahu4real12@gmail.com
}

\begin{abstract}
This study employs the cointegration technique and the granger causality test to examine the impact and the causal relationship between money supply and economic growth in Nigeria using annual time series data spanning 1980 to 2017. After critical exploration of both the theoretical and the empirical literature, the study concludes that money supply has a positive impact on economic growth. This is evidenced by the presence of cointegrated and long-run relationship among the variables. In addition, the Granger causality test shows the existence of unidirectional causality running from money supply to economic growth, hence result is consistent with numerous empirical literature. As such, government should put in place other policy measures that would encourage the effective workings of money supply in Nigeria. This may include proper engagement of monetary management to ensure that increase money supply does not lead to economic disorder in the long-run.
\end{abstract}

Keywords: Money Supply, Economic Growth, Cointegration, Granger Causality, Nigeria.

\section{Introduction}

In the contemporary economy, money supply is a crucial element for accelerating the pace of economic growth of countries and further plays a vital role in the determination of price level, unemployment and interest rate. However, increasing concern in the literature of monetary economics on the impact of money supply on economic growth has continued to surface hence, attracting global attention and gradually becoming a major debatable domain among different schools of thought, but the arguments involved are numerous, extensive and some in some cases quite technical. Various scholars have different submissions to this effect, while some agreed that variations in the quantity of money is the major crucial factor to economic growth and that countries who allocate greater time to examine the behaviours of aggregate money stock experiences high variations in the aggregate economic activities ((Harding \& Pagan, 2001); others still remain uncertain regarding the role of money supply on the economy (Canetti \& Greene, 2000). In other words, the 
INTERNATIONAL JOURNAL OF ACADEMIC RESEARCH IN BUSINESS AND SOCIAL SCIENCES Vol. 9, No. 7, July, 2019, E-ISSN: 2222-6990 @ 2019 HRMARS

Monetarists rely on the assertion that money supply affects price level not real GDP or unemployment, while the Keynesians argued that changes in money supply leads to changes in real output and prices. In another context, Monetarist argued that variation in the level of money supply causes an unexpected changes in the nominal income due to stability of money, whereas Friedman assumes that it is the most stable function; and the Keynesians assume that the role of money supply is very limited because of the liquidity trap and the investment elasticity of interest is also low. Hence, the positive variations in income resulted to increasing money demand for transactions and rising the level of money. Due to the high significance of economic growth among other macroeconomic objectives of any country, increasing concern has always been given in the literature (particularly the Monetarist and the Keynesians) on the role of money supply on economic growth of both developed and developing nations.

Notwithstanding, when evaluating the effects of money supply on economic growth, certain factors like unemployment and unsteady price cannot be undervalued. This is because, monetarist argued that increase in money supply can cause an eventual rise in the general price level; hence leading to more inflationary pressure within the domestic economy. Given the price hike due to excess money supply, consumers are therefore forced to reduce consumption on essential goods and services; hence affecting the market conditions and largely causing unemployment. Irrefutably, Nigeria usually encounter unemployment and fluctuating price level in its monetary management. The monetary management consist of experts who oversee and control the relationship between the prices of borrowed money (interest rate) and the aggregate money supply in the country towards realising sustainable development. Attaining a sustainable economic growth and development is certainly one of the major challenges of the Nigerian economy. As such, issues related to growth patterns, understanding the determinants of economic growth and the reaction of domestic production to shocks or innovations resulting from the money supply are essential and critical elements to the growing economy.

Over the years, money supply (M2) in Nigeria has been on the rising trend, increasing from \#14.39 billion in 1980 to 14.47 billion in 1981 equating to $28.6 \%$ and $29.45 \%$ of the GDP, respectively. From 1982 up to the period of the Structural Adjustment Programme (SAP) in 1986, the broad money supply has tremendously increased to over $30 \%$ of the GDP in the respective years. The decline in the world oil price coupled with the repercussion of the SAP has severely affected the output growth and further caused numerous destructions. Even though the trend of money supply was on the increase, it effects on the economic activities was marginal. In 1990, it was \#52.86 billion or $20.44 \%$ of the GDP and further risen up to $26.66 \%$ of the GDP in 2001. From 2016 to 2017, the irregular increase in inflation rate has resulted to decline in societal welfare and a gradual deterioration in output level of the economy causing economic rigidities and imbalances within the monetary base of the economy. This can be observed by the declining rate of the GDP from $\$ 69,023.93$ billion in 2015 to $\$ 67,931.24$ billion in the year 2016 hence derailing the economy to the state of recession. The implementation of Economic Recovery and Growth Plan (ERGP) by the Nigerian government in addition to other policy measures, has revive the economy towards attaining sustainable growth and development.

Like many developing nations in the sub-Saharan region, Nigeria is passing through a significant process of liberalization with many of its sound macroeconomic indices lying in an alarming situation. In addition to socio-economic menace, the political stability still remains uncertain. Moreover, the 
current economic realities in Nigeria necessitated the need for further studies to re-examine the impact of macroeconomic indicators (including money supply) on the real GDP with the view to determining a sound policy approach towards realizing its growth potentials, hence the need for this study. Previous literature in Nigeria had adopted various techniques with limited frequency and outof-date data hence, are far from reaching a decisive consensus on the precise impact of money supply on economic growth.

In view of this, the main thrust of this study is to examine the effect of money supply on economic growth using recent and up-to-date annual data from the archive of Central Bank of Nigeria (CBN) and the National Bureau of Statistic (NBS). Since the study period covers some of the significant economic and political transformations leading to a more and open liberalised Nigerian state, it would further enriches the existing literature on the relationship between these essential macroeconomic indicators. This mechanism would expedite the process and assist in evaluating the extent to which money supply has impacted on the output growth of the Nigerian economy. Moreover, the conclusions from this study would provide the needed scaffold and serve as a working tool to the government and policy analyst in further understanding the relationship between money supply and economic growth in developing countries.

The rest of the study is divided into several sections: section 2 deals with the empirical literature by various authors from both developed and developing countries on the role of money supply in enhancing output level; section 3 provides the source and nature of the utilised data as well as the techniques of analysis; section 4 presents the empirical results and other empirical findings in relation to the study objective; and finally section 5 concludes the study and provides a number of policy recommendations to the monetary management and other policy makers in Nigeria and by extension the developing countries.

\section{Review of the Empirical Literature}

Various studies in the literature have examined the role or impact of money supply on economic growth among developed and developing countries, but the results remain inconsistent. A good number of these studies include the followings: Ditimi, Sunday and Onyedikachi (2017) evaluate the causal nexus between money supply and inflation in Nigeria by employing the time series data covering 1970 to 2016. The authors used the cointegration approach and the Autoregressive Dynamic Error Correction Model (ADLECM) to estimate the relationship. Result shows no evidence of either short-run or long-run relationship, hence money supply does not influence inflation. In addition, the granger causality also shows no causality link between the two variables. Furthermore, He (2016) examines the relationship between money supply and some selected macroeconomic variables including the real GDP, the inflation rate and the interest rate in China. The author utilised the annual time series data covering 2000 to 2016 to analyse the relationship using the Vector Auto Regression (VAR) technique. Results shows that an increase in money supply leads to a higher rise in real GDP and inflation but decrease in the interest rate.

In addition, Chaitip, Chokethaworn, Chaiboonsri and Khounkhalax (2015) examine the relationship between money supply and economic growth-wide phenomena of AEC open region comprising of Thailand, Indonesia, Singapore, Malaysia, Philippines, Vietnam, Lao PDR and Cambodia. Panel ARDL of Pooled Mean Group Estimator (PMGE) is conducted on the annual data spanning 1995 to 2013 to 
observe the short-run and the long-run relationships. Findings reveal that money supply is associated with the economic growth of countries under consideration. More so, Ihsan and Anjum (2013) examine the impact of money supply on economic growth in Pakistan. The authors utilised the inflation rate, Consumer Price Index (CPI) and interest rate for the period of 2000 to 2011 using the regression model. Results indicate that the excess pumping of money supply (M2) by the State Bank of Pakistan into the economy might leads to high rate of inflation especially when certain indicators such as CPI and interest rate are not economically managed.

Similarly, Yan-liang (2012) empirically analyses the relationship between money supply, inflation and economic growth in China using annual data spanning 1998 to 2007. The author employed the cointegration approach and the granger causality technique with the view to evaluating the relationship. For the period under review, result shows no evidence of cointegrating relationship between the money supply and economic growth in China. Likewise, Ogunmuyiwa and Ekone (2010) assess the impact of money supply on the economic growth of Nigeria using annual data from 1980 to 2006. To determine the causal relationship, ordinary least square technique and the error correction model are employed to estimate the collected data. Finding shows that money supply is positively related to economic growth while the direction of causality shows no significant and predictive power in explaining the relationship between money supply and economic growth. However, Tabi and Ondoa (2011) analyse the relationship between economic growth, inflation and money supply in Cameroon using a VAR model for the period of 1960 to 2007. Estimated results indicate a positive impact between money supply and economic growth and that growth causes inflation. On the other hand, an increase in money supply does not necessarily increase the rate of inflation.

In another development, Aslam and Lebbe (2015) uses the annual data (from 1959 to 2013) to determine the relationship between money stock and economic growth in Sri Lanka by employing a regression model and the Augmented Engel-Granger (AEG) technique. Estimated result reveals the presence of a positive and stable relationship between the money stock and economic growth of Sri Lanka during the period under review, while the AEG testing analysis also established the existence of a significant relationship between the variables in Sri Lanka. Moreover, El-Seoud (2014) employs the annual data from 2000 to 2013 to determine the direction of causality between the money supply and real Gross Domestic Product (GDP) in both the short-run and long-run. The author utilises the cointegration technique, error correction model, and granger causality techniques to determine the relationship between the money supply and real GDP in Bahrain. The cointegration test indicates the existence of long-run equilibrium relationship between the money supply and real GDP based on Engle-Granger two steps test. The study therefore concludes that money supply had neutral effect on the real GDP growth in Bahrain.

Similar to this, Sahin and Dogan (2017) discuss the neutrality of money hypothesis in terms of level and volatility effects of money supply using data spanning 1959 to 2016 . To estimate the results, mean equation of EGARCH model, Asymmetric Dynamic Conditional Correlation Model (ADCCEGARCH) and the Detrended Cross Correlation Analysis (DCCA) are adopted for the analysis. Findings reveal a positive long run relationship between money supply and output levels. In addition, a nonneutrality of money supply in the short-run and the dynamic conditional correlations vary over time. In addition, Siyan and Adegoriola (2015) investigate the relative impacts of money supply and 
INTERNATIONAL JOURNAL OF ACADEMIC RESEARCH IN BUSINESS AND SOCIAL SCIENCES Vol. 9, No. 7, July, 2019, E-ISSN: 2222-6990 @ 2019 HRMARS

government expenditure on economic growth in Nigeria using beta coefficients technique and 2stage least square estimator. Findings indicate a weak impact of money supply on economic growth compared to the government expenditure. In other words, government expenditure has a strong and significant impact relative to money supply on economic growth.

More to that, Oluseyi, Olasehinde and Eweke (2017) examine the short-run and the long-run relationship between broad money supply and the real GDP in Nigeria using data from 1981 to 2015. The U-MIDAS results establish the presence of short-run and long-run relationship between the annual real GDP and the quarterly broad money supply at different seasons while the ARDL result shows that money supply has a positive and significant impact on the real GDP. Also, Tabar, Najafi and Badooei (2016) examine the short-run and the long-run relationship between money supply, inflation and government expenditure on economic growth of Iran. Data spanning the period of 1981 to 2011 is employed and estimated using the Autoregressive Distributed Lag (ARDL) model. Result shows the positive impacts of money supply and other variables on economic growth.

Furthermore, Hussain and Zafar (2018) examine the causal relationship between money supply, inflation, government expenditure and economic growth in Pakistan spanning 1972 to 2015. To estimate the results and provide a valid finding, ARDL model and the granger causality test are adopted. Finding indicates a strong impact of money supply government expenditure and inflation on economic growth. More so, Hussain and Haque (2017) assess the impact relationship between money supply and per capita GDP growth rates in Bangladesh for the period of 1972 to 2014 using a Vector Error Correction Model (VECM). Result indicates that a steady broad money supply is associated with per capita GDP and money supply has significant and essential impact on the growth rate of output in the long-run. Also, Mohammad, Wasti, Lal and Hussain (2009) examine the relationship between broad money supply, inflation, government expenditure and economic growth in Pakistan. Data is obtained for the period of 1977 to 2007 and estimated using the Johansen cointegration technique and the granger causality test. Result establishes that broad money supply (M2) has a positive impacts on economic growth particularly in the long-run period.

To further provide empirical evidence, Dingela and Khobai (2017) investigate the dynamic impacts of broad money supply on economic growth per capita in South Africa. The author used the annual data from 1980 to 2016 on the ARDL technique to examine the effects of money supply on GDP per capita. Result shows the existence of a significant and positive relationship between money supply and economic growth both in short-run and long-run. Similarly, Njimanted, Akume and Mukete (2016) examine the impacts of key monetary variables on the economic growth of CEMAC zone covering the period of 1981 to 2015. Using the Vector Autoregression (VAR) model, result shows that money supply, interest rate, and inflation influence the economic growth of CEMAC zone in different ways with inflation rate as the impact factor. On the other hand, Denbel, Ayen and Regasa (2016) examine the causal relationship between money supply, inflation and economic growth in Ethiopia for the period of 1970 to 2011. To estimate the result, Johansen cointegration and the VECM technique are adopted. Finding shows the existence of short-run and long-run relationship among the examined variables.

Nevertheless, Gatawa, Abdulgafar and Olarinde (2017) assess the impact of money supply, inflation and interest rate on economic growth in Nigeria using annual data covering the period of 1973 to 2013. To provide a valid finding, the VAR model, VECM technique and the granger causality test are 
INTERNATIONAL JOURNAL OF ACADEMIC RESEARCH IN BUSINESS AND SOCIAL SCIENCES Vol. 9, No. 7, July, 2019, E-ISSN: 2222-6990 @ 2019 HRMARS

adopted. Result establishes a positive and significant impact of broad money supply on economic growth, while inflation and interest rate exhibits a negative impact on growth most especially in the long-run period. Conversely, Aslam (2016) investigates the impacts of money supply on the Sri Lankan economy using the annual data covering the period of 1959 to 2013. The author adopted the multivariate econometrics method to test the impacts of the model coefficients. Finding establishes that money supply has a positive and significant on the economic growth of Sri Lankan. Equally, Ogunmuyiwa and Ekone (2010) examine the impact of money supply on the economic growth of Nigeria using annual data covering the period of 1980 to 2006. The author adopts the ordinary least square estimator and the error correction model to conduct the analysis. Results indicate a positive impacts of money supply on economic growth but it is insignificant in the case of GDP growth rates on the choice between contractionary and expansionary money supply.

However, Ahmed and Suliman (2011) evaluate the long-run relationship between money supply, price level and the real GDP in Sudan using the annual data covering the period of 1960 to 2005. The authors employ the cointegration technique and the granger causality test for the analysis. Findings indicate the existence of long-run relationship among the variables, however, there is no causality between money supply and the real GDP for the period under consideration. In the same vein, Olatunji, Sunday and Omolara (2012) examine the dynamic causality between money supply and some selected macroeconomic indicators including the output level, interest rate, exchange rate and the price. The authors used the annual data from Nigeria covering the period of 1960 to 2011 and employed the Johansen cointegration technique, the VECM, the granger causality test, impulse response functions and its corresponding variance decomposition. Findings establish the presence of long-run and short-run relationship among the macroeconomic variables. Furthermore, the presence of causal relationship among the variables reveal that money supply is neutral in the short-run and cannot be efficient in the stabilization of both output and price level.

In support of the causality relationship, Soufan and Al Zaytoonah (2013) examine the causal relationship between money supply and the real GDP in Jordan using the granger causality method with the view to determining the direction of causality among the examined variables. The authors utilised the annual data spanning the period of 1978 to 2010 to draw verification. Results indicate a causal relationship running from the money supply to the real GDP. While, Sola and Peter (2013) investigate the impact of money supply and inflation rate in Nigeria using time series data covering the period of 1970 to 2008 . The authors utilise the VAR model to estimate the model coefficients. Result shows the existence of unidirectional causality between money supply and inflation rate as well as interest rate and inflation rate. The causality test runs from money supply to inflation, from the interest rate to inflation and from interest rate to money supply.

More so, Behera (2016) investigates the dynamics of inflation, real GDP, exchange rate and money supply in India covering the period of 1975 to 2012. The author used the VECM and the granger causality technique to determine the direction of the relationship. Findings indicate that exchange rate Granger causes both GDP and money supply at 10 percent level of significance. Furthermore, the impulse response result shows that GDP has a positive response to money supply from the occurrence to the end of the period. Additionally, Koti and Bixho (2016) examine the different approaches and related theories of money supply and inflation, and further analyses the theoretical links of money supply with unemployment, trade and exchange rate, taxes and wages in Albania. 
Using the regression analysis, empirical results show that money supply has strong relationship with economic growth, interest rate and inflation, but money supply has a negative sign toward inflation. In addition, further results indicate that all money supplied by the financial system is fully absorbed by the private sector and individuals, without causing an increase on the inflation level.

In addition, Bonga (2015) examines the increase in money supply and its impact on the Zimbabwean economy. The study is based on contextual analysis, hence evaluating several phenomenon of money supply in the economy. The study indicates that a well-managed local currency is a strategic tool which the country can use to influence trade with other countries. But, introducing and managing expansion of a currency is not easy especially when the currency was previously rejected due to loss of value related to poor macroeconomic policies. Adding to this, Georgantopoulos and Tsami (2013) examine the relationship between money supply, inflation, government and economic growth in Cyprus over the sample period of 1980 to 2009. The authors employed the error correction mechanism, Johansen cointegration test and the granger causality test with the view to determining the direction of the relationship among the examined variables. Findings indicate that excess growth of money supply impose high inflationary pressure on the economy. Therefore, money supply should be allowed to grow according to the real output of the economy. Contrary to this assertion, Amassoma, Sunday and Onyedikachi (2018) investigate the impact of money supply and inflation in Nigeria over a sample period of 1970 to 2016. Cointegration and the error correction mechanism are used to ascertain short-run and long-run dynamic relationship among the variables. Result shows that money supply does not considerably influence inflation both in the short-run and the long-run. According to Sturgill (2014), the positive influence between money supply and economic growth may be due to higher levels of economic freedom in more developed nations, which can create an enabling environment where nominal money helps facilitate the production process or expedites capital accumulation. The author examine the causal relationship between the money supply and economic growth among selected OECD countries. The author performs a cross-country growth analysis and further utilises the VAR model and the granger causality test for the estimation. Findings show that money growth encourages and drive economic growth in the selected OECD countries. However, Morteza and Farahani (2016) evaluate the influence of moneys supply and the impacts of shocks on real economy in countries that are natural-resources-dependent. Using data from 1990 to 2013 on the panel model and VECM technique, results in all cases establish that negative monetary shocks had far more effects than positive monetary shocks in the same period. Furthermore, positive monetary shocks had a negative effect on output growth, as in the case of implementation of monetary policy after a period based on adjustment of the price.

Adding to the argument, Marshal (2016) examines the causal link between money supply and economic growth in Nigeria using time series data covering the sample period of 1970 to 2014. The author utilised the VAR model and the cointegration technique to further determine the impact of the variables. Result shows a positive and significant relationship between money supply and real GDP in Nigeria. On causality, there is a causality running from money supply to real GDP and not vice versa. This shows that there is unidirectional causality from money supply to Real GDP in Nigeria for the period under consideration. To show further evidence, Anyanwu and Kalu (2015) examine the relationship between money supply and economic growth in Nigeria and further ascertain the extent of correlation that exists between money supply and real GDP using time series data spanning 1994 
to 2012. A statistical software package (SPSS) is employed for the analysis, hence result shows that changes in money supply (M2) has a significant and positive impact on the real output growth in Nigeria.

However, Singh, Das and Baig (2015) uses different metrics for money supply, output and prices to understand and examine the relationship between the variables. Granger causality and the cointegration test are conducted on the time series data with the view to determining its statistical significance. Findings indicate that the relationship between money supply and the output is unidirectional, hence money supply granger cause output. Correspondingly, Ifionu and Akinpelumi (2015) examine the money supply, inflation and exchange rate on the real GDP in Nigeria. The authors utilised the annual time series data covering the 1981 to 2013 , and adopts the cointegration test and the causality technique to estimate the short-run and the long-run relationship among the variables. Result shows that money supply and the exchange rate have positive and significant impact on the real GDP while inflation exerts a negative influence on the money supply.

\section{Data and the Measurement of Variables}

In this study, annual time series data spanning the period of 1980 to 2017 are obtained from the archive of Central Bank of Nigeria (CBN) and the National Bureau of Statistic (NBS) thus, includes the broad money supply (M2) and the real GDP (proxy for economic growth). Moreover, the values of the variables are define in constants prices (2010 base year) and measured in billions of local currency in Nigeria ( naira). The values are further transformed into logarithms with the view to reducing the problem of multicollinearity, heteroskedasticity and attained a reliable estimates which in turn ensures actualising elasticity's rather than slope hence making the variables to appear more symmetric (Gujarati \& Porter, 2009). Conceptually, money supply is the total amount of monetary assets available in an economy at a particular time. This can further be elaborated by including currency in circulations and demand deposits of financial institutions. The Central Bank of Nigeria has the sole responsibility of recording, reporting and publishing the status of money supply in the country.

There are different measurements of money supply and all the dimensions are extensively used in the literature. These include the $\mathrm{M} 0$ and $\mathrm{M} 1$, also called narrow money supply, usually include coins and notes in circulation and other money equivalents that are easily convertible into cash. M1 is the sum of currency plus demand deposits, traveller's checks, and other checkable deposits. The rationale for holding M1 is to utilise it as a medium of exchange to purchase various goods, labour services and securities. It is the most liquid financial asset that is held by public (Ihsan \& Anjum, 2013). However, $\mathrm{M} 2$ also called broad money supply is the sum of M1 and the near money which is the sum of the resident savings deposits, time deposit of enterprises and other deposits. In lieu of that, this study uses the broad money supply (M2). On the other hand, the real GDP refers to the total value of all final goods and series produced within a country over a period of time.

\section{Techniques of Analysis}

To determine the impact and the causal relationship between money supply and the economic growth, Johansen cointegration test and the Granger causality test are employed to assist in the estimation. 


\section{Johansen Cointegration Test}

The Johansen cointegration test is a statistical method for testing the cointegration relations among the variables. The test is based on VAR model of order $p$ to examine the long-run relationship that may possibly exist between the broad money supply and real GDP (proxy for economic growth). If $X_{t}$ and $Y_{t}$ are integrated of order one, or $X_{t} \sim 1(1)$ and $Y_{t} \sim 1(1)$; then, $X_{t}$ and $Y_{t}$ are said to be cointegrated if and only if $\mu_{\mathrm{t}}$ obtained from the long-run relationship regression is integrated of order zero or $\mu_{\mathrm{t}} \sim$ 1(0). Therefore, if the cointegration condition is met, then $X_{t}$ and $Y_{t}$ move together in the long-run such that they cannot drift arbitrarily far apart from each other as time goes (Brooks, 2008). In other words, when two series has the same stochastic trend, they are said to be cointegrated. More so, the Johansen cointegration test depends on the Maximum Likelihood (ML) estimator of the parameters involved while taking into cognisance the significance of trace statistics and the maximum Eigen value statistics. And it is a crucial test for the existence of long relationship among variables. Undeniably, this approach depends strongly on the relationship between the rank of a matrix and its characteristic roots (Gujarati \& Porter, 2009).

\section{Granger Causality Test}

The Granger causality test is another estimation technique that depicts whether lagged values of one variable helps to predict another variable. It is the $\mathrm{F}$ statistic testing of the hypothesis that the coefficients on all the values of one variables in the equation are zero. In addition, Granger causality means that if $I_{t}$ granger causes $G_{t}$, then, $I_{t}$ is a useful predictor of $G_{t}$ whereas past values of $G_{t}$ don't help to predict $I_{t}$ when controlling for past values of $I_{t}$. It does not mean that change in $I_{t}$ causes subsequent change in $G_{t}$. In summary, while the cointegration test depicts the possible relationship, the Granger causality test determine the direction of causality between money supply and the real GDP.

\section{Results and Discussions}

In this section, the estimated results are presented and discussed in relation to the study objective. These includes results from the unit root testing, cointegration analysis and the VAR Granger causality test.

\section{Results of Unit Root Testing}

In order to determine the stationarity or otherwise of the data, unit root tests are conducted using the Augmented Dickey-Fuller (ADF) test and the Phillips-Perron (PP) test taking into cognizance the examined variables under consideration, namely; the real GDP and the broad money supply. The results are estimated in two forms; without linear trend and with linear trend in both the ADF and PP tests respectively. These results are presented in Table 1.1 as follows: 
INTERNATIONAL JOURNAL OF ACADEMIC RESEARCH IN BUSINESS AND SOCIAL SCIENCES Vol. 9, No. 7, July, 2019, E-ISSN: 2222-6990 @ 2019 HRMARS

Table 1.1: Unit root test

\begin{tabular}{|l|l|l|l|l|l|l|l|l|}
\hline \multirow{3}{*}{ Variables } & \multicolumn{4}{|c|}{ ADF test } & \multicolumn{4}{c|}{ PP test } \\
\cline { 2 - 9 } & Without Trend & With Trend & \multicolumn{2}{|l|}{ Without Trend } & \multicolumn{1}{c|}{ With Trend } \\
\cline { 2 - 9 } & Level & $\mathbf{1}^{\text {st }}$ Dif. & Level & $\mathbf{1}^{\text {st }}$ Dif. & Level & $\mathbf{1}^{\text {st }}$ Dif. & Level & $\mathbf{1}^{\text {st }}$ Dif. \\
\hline RGDP & 0.9817 & $0.0199^{*}$ & 0.1582 & $0.0510^{* *}$ & 0.9939 & $0.0202^{*}$ & 0.5332 & $0.0457^{*}$ \\
\hline MS & 0.7608 & $0.0187^{*}$ & 0.8116 & $0.0856^{* *}$ & 0.9310 & $0.0205^{*}$ & 0.5301 & $0.0964^{* *}$ \\
\hline
\end{tabular}

Note: *stationary at $5 \%$ level, ${ }^{* *}$ stationary at $10 \%$ level

Results in Table 1.1 shows the estimated findings from the unit root testing based on the ADF and the PP tests, respectively. For clarity, a null hypothesis for the existence of unit root among the variables is adopted. It can be observed from the Table 1.1 that variables are significant in ADF test at $5 \%$ level when there is no trend. With the inclusion of linear trend, both RGDP and MS became stationary at $10 \%$ level. For the PP test, the variables are first difference stationary (5\% level) either with or without trend except MS which is stationary at $10 \%$ level. This implies that all variables are stationary at first difference I(1), hence proving ground support for further estimating the long-run relationship.

\section{Results of the Cointegration Test}

The existence of possible long-run relationship among the variables in the model is determined using the cointegration approach. In this study, Johansen cointegration test is employed to evaluate this relationship and provides further justification for the combined use of both the dependent and the independent variables in a single model. The result for this test is presented as follows:

Table 1.2: Results of the cointegration test

Sample (adjusted): 19862017

Included observations: 32 after adjustment

Series: LRGDP LMS

Lags interval: 1 to 5

\begin{tabular}{|c|c|c|c|c|c|c|}
\hline \multirow{2}{*}{$\begin{array}{l}\text { Hypothesised } \\
\text { no. of } \\
\text { cointegrating } \\
\text { equations }\end{array}$} & \multicolumn{3}{|c|}{ Trace Statistic } & \multicolumn{3}{|c|}{ Maximum Eigenvalue } \\
\hline & $\begin{array}{l}\text { Trace } \\
\text { statistic }\end{array}$ & $\begin{array}{l}0.05 \\
\text { critical } \\
\text { value }\end{array}$ & P-value & $\begin{array}{l}\text { Max-Eigen } \\
\text { value }\end{array}$ & $\begin{array}{l}0.05 \\
\text { critical } \\
\text { value }\end{array}$ & P-value \\
\hline Zero* & 24.50 & 15.49 & $0.0017 * *$ & 19.04 & 14.26 & $0.0081 * *$ \\
\hline At most $1^{*}$ & 5.46 & 3.84 & $0.0194 * *$ & 5.46 & 3.84 & $0.0194 * *$ \\
\hline
\end{tabular}

Note: ${ }^{*}$ denotes rejection of the hypothesis at $5 \%$ level

**Mackinnon Haug-Michelis (1999) p-values

Results from Table 1.2 shows the test of unrestricted cointegration for the estimated model. The standard statistics used in the interpretation of this test are the trace statistic and the maximum eigenvalue at a given level of significance. It should be noted that the first column from Table 1.2 indicates the hypothesised number of cointegrating equations as revealed by both the trace statistic and the maximum eigenvalue test with their corresponding probability values at $5 \%$ level. The results 
INTERNATIONAL JOURNAL OF ACADEMIC RESEARCH IN BUSINESS AND SOCIAL SCIENCES Vol. 9, No. 7, July, 2019, E-ISSN: 2222-6990 @ 2019 HRMARS

show the existence of two (2) cointegrating relationship among the variables as revealed by the trace statistics and the maximum eigenvalue statistics, respectively. Hence, necessitating the rejection of the null hypothesis of no cointegrating relationship at $5 \%$ level. Furthermore, the results have established the presence and existence of a long-run relationship between money supply and the real GDP in Nigeria.

\section{Results of the Granger Causality Testing}

As hitherto, the granger causality test assists in determining the direction of causality among the examined variables. Since all the variables are first difference stationary or integrated of order one $\mathrm{I}(1)$, the Granger causality is applied using the first differences of both real GDP and the money supply. The result is presented in Table 1.3 as follows:

Table 1.3: Result of the Granger causality test

\begin{tabular}{|l|l|l|l|}
\hline Null hypothesis & Chi-square & P-value & Decision \\
\hline$\Delta \mathrm{LRGDP}_{\mathrm{t}}$ does not granger cause $\Delta \mathrm{LMS}_{\mathrm{t}}$ & 6.786 & 0.2370 & Do not reject the null \\
\hline$\Delta \mathrm{LMS}_{\mathrm{t}}$ does not granger cause $\Delta \mathrm{LRGDP}_{\mathrm{t}}$ & 14.196 & $0.0144^{*}$ & Reject the null \\
\hline
\end{tabular}

Note: $*$ indicates significance at $5 \%$ level

From the Granger causality estimation in Table 1.3, findings indicate that economic growth does not granger-cause money supply since the probability value is insignificant at any level, hence the null hypothesis of no causality cannot be rejected. This implies that economic growth does not predict anything about the long-run behaviour of money supply in Nigeria. The result is consistent with the theoretical assertion of Monetarists who assumed that money supply affects price level not real GDP or unemployment level. On the other hand, the result shows that money supply granger-cause economic growth since the probability value of 0.0144 is significant at $5 \%$ level. Because of the fact that the lagged values of real GDP have incremental forecasting power when added to equation of money supply in the univariate autoregressive model. The first null hypothesis cannot be rejected which means that real GDP does not Granger causes money supply. However, the second null hypothesis is rejected implying that money supply Granger cause real GDP. Therefore, it is a unidirectional causality running from $L M S_{t}$ to $L R G D P_{t}$ indicating the existence of long-run relationship among the variables. The result is consistent with the literature as submitted by Hussain and Zafar (2018); Aslam (2016). By implications, it means that changes in money supply helps in explaining the changes in economic growth, while variations in economic growth does not helps in explaining the variations in money supply both in the short-run and the long-run, hence monetary policy in Nigeria has a significant impact on economic growth.

\section{Conclusion}

This study examines the impact and the causal relationship between money supply and economic growth in Nigeria. After critical exploration of both the theoretical and the empirical literature, the study concludes that money supply has a positive impact on economic growth. This is evidenced by the presence of cointegrated and long-run relationship among the variables in addition to the unidirectional linkage running from money supply to economic growth. Despite the upward increase in monetary aggregates during the last decade, its significance towards sustainable growth and 
development in Nigeria still remains debatable. Hence, government should harmonise the activities of financial institutions to reduce the interest rate differential between productive and unproductive loanable credit supplied to the economy. This would increase the flow of goods and services from the private sector of the economy, hence widening the domestic market and raise employment level at the long-run. In addition, government should put in place other policy measures that would encourage the effective operations of money supply in Nigeria. This may include proper engagement of monetary management to ensure that increase money supply does not lead to economic disorder in the long-run. In such case, government might use the inflation rate as a yardstick for determining the efficiency of the monetary management.

The study is considered timely in Nigeria particularly at a time when most policies aimed at ensuring sustainable growth seems to have failed in producing the desired results. Given the current efforts by the federal government to reduce deficits and inflation rate as well as strengthen accountability framework in the public management of resources, evaluating the impact of money supply is a significant contribution to the Nigeria economy. The concept is a powerful tool in strengthening the position of monetary authorities on output growth and stability. Understanding the impact of money supply on economic growth is expected to serve as a working tool for policy makers to design feasible policy strategies that can contribute to the actualisation of sustainable growth and development of the Nigerian economy.

\section{Reference}

Ahmed, A. E. M., \& Suliman, S. Z. (2011). The long-run relationship between money supply, real GDP, and price level: Empirical evidence from Sudan. Journal of Business Studies Quarterly, 2(2), 68-79.

Amassoma, D., Sunday, J., \& Onyedikachi, E. (2018). The influence of money supply on inflation in Nigeria. Journal of Economics and Management, 31(1), 05-23.

Anyanwu, U. N., \& Kalu, A. O. U. (2015). The impact of statutory money supply management and commercial bank loans and advances (CBLA) on economic growth: An empirical evidence in Nigeria. Arabian Journal of Business and Management Review (Nigerian Chapter), 3(5), 0118.

Aslam, A. L. M. (2016). Impact of money supply on Sri Lankan economy: An econometric analysis. International Letters of Social and Humanistic Sciences, 67, 11-17.

Aslam, A. L. M., \& Lebbe, S. M. A. (2015). The relationship between money stock and economic growth of Sri Lanka: An AEG testing approach. 5th International Symposium 2015 - IntSym 2015, SEUSL.

Behera, J. (2016). Dynamics of inflation, economic growth, money supply and exchange rate in India: Evidence from multivariate analysis. Quarterly Journal of Econometrics Research, 2(2), 42-54.

Bonga, W. G. (2015). Is Increased Money Supply a Solution to Boost Zimbabwe Economic Growth Path? Social Science Research Network (SSRN).

Available at: http://ssrn.com/abstract=2696669

Brooks, C. (2008): Introductory Econometrics for Finance ( $2^{\text {nd }}$ edition). ICMA Center University of reading; Cambridge university press; New York. 
INTERNATIONAL JOURNAL OF ACADEMIC RESEARCH IN BUSINESS AND SOCIAL SCIENCES

Vol. 9, No. 7, July, 2019, E-ISSN: 2222-6990 @ 2019 HRMARS

Canetti, E., \& Greene, J. (2000). Monetary growth and exchange rate depreciation as causes of inflation in African Countries. International Monetary Fund, Washington, D.C.: World Bank Working Paper.

Chaitip, P., Chokethaworn, K., Chaiboonsri, C., \& Khounkhalax, M. (2015). Money supply influencing on economic growth-wide phenomena of AEC open region. Procedia Economics and Finance, 24 108-115.

Denbel, F. S., Ayen, Y. W., \& Regasa, T. A. (2016). The relationship between inflation, money supply and economic growth in Ethiopia: Cointegration and causality analysis. International Journal of Scientific and Research Publications, 6(1), 556-565.

Dingela, S., \& Khobai, H. (2017). Dynamic impact of money supply on economic growth in South Africa. An ARDL approach. Munich Personal RePEc Archive (MPRA), MPRApaper no. 82539.

Ditimi, A., Sunday, K., \& Onyedikachi, E. O. (2017). The upshot of money supply and inflation in Nigeria. Valahian Journal of Economic Studies, 8-22(2), 75-90.

El-Seoud, M. S. A. (2014). Testing the relationship between money supply and GDP in Bahrain.International Journal of Economics, Commerce and Management, II(5), 01-16.

Gatawa, N. M., Abdulgafar, A., \& Olarinde, M. O. (2017). Impact of money supply and inflation on economic growth in Nigeria. IOSR Journal of Economics and Finance (IOSR-JEF), 8(3/4), 26-37.

Georgantopoulos, A. G., \& Tsami, A. D. (2013). The interrelationship between money supply, prices and government expenditures and economic growth: A causality analysis for the case of Cyprus. International Journal of Economic Sciences and Applied Research, 5(3), 115-128.

Gujarati, D. N., \& Porter, D. (2009). Basic Econometrics, $3^{\text {rd }}$ edition. US: The McGraw-Hill

Harding, D., \& Pagan, A. (2001). Extracting, analysing and using cyclical information. MPRAPaper No.15

He, Y. (2016). A study on the relationship between money supply and macroeconomic variables in China. Mediterranean Journal of Social sciences, 8(6), 99-107.

Hussain, M. E., \& Haque, M. (2017). Empirical analysis of the relationship between money supply and per capita GDP growth rate in Bangladesh. Journal of Advances in Economics and Finances, 2(1), 54-66.

Hussain, M. I, \& Zafar, T. (2018). The interrelationship between money supply, inflation, public expenditure and economic growth. European Online Journal of Natural adSocial Sciences, 7(1), 01-24.

Ifionu, E., \& Akinpelumi, O. F. (2015). Macroeconomic Variables and Money Supply: Evidence from Nigeria. An International Multidisciplinary Journal, Ethiopia. African Research Review (AFRREV), 9/4(39), 288-307.

Ihsan, I., \& Anjum, S. (2013). Impact of money supply (M2) on GDP of Pakistan. Global Journal of Management and Business Research, 13(6), 01-08.

Koti, S., \& Bixho, T. (2016). Theories of money supply: The relationship of money supply in a period of time $\mathrm{T}_{-1}$ and inflation in Period T- empirical evidence from Albania. European Journal of Multidisciplinary Studies, 1(1), 294-302.

Marshal, I. (2016). The link between money supply and economic growth in Nigeria: an econometric investigation. International Institute of Academic Research and Development (IIARD). International Journal of Economics and Business Management, 2(3), 42-51. 
INTERNATIONAL JOURNAL OF ACADEMIC RESEARCH IN BUSINESS AND SOCIAL SCIENCES

Vol. 9, No. 7, July, 2019, E-ISSN: 2222-6990 @ 2019 HRMARS

Mohammad, S. D., Wasti, S. K. A., Lal, I., \& Hussain, A. (2009). An empirical investigation between money supply, government expenditure, output \& prices: the Pakistan evidence. European Journal of Economics, Finance and Administrative Sciences 17, 60-68.

Morteza, E., \& Farahani, Y. G. (2016). The relationship between money supply and economic activity in countries dependent on natural resources. Journal of Economics and Sustainable Development, 7(7), 21-29.

Njimanted, F. G., Akume, D., \& Mukete E. M. (2016). The impact of key monetary variables on the economic growth of the CEMAC Zone. Expert Journal of Economics, 4(2), 54-67.

Ogunmuyiwa, M. S., \& Ekone, A. F. (2010). Money supply-economic growth nexus in Nigeria. Journal of Social Sciences, 22(3), 199-204.

Ogunmuyiwa, M. S., \& Ekone, A. F. (2010). Money Supply - Economic Growth Nexus in Nigeria. Journal of Social Sciences, 22(2), 199-204.

Olatunji, T. M., Sunday, A. A., \& Omolara, Y. J. (2012). The dynamic causality between money and macroeconomic activity: Empirical evidence from Nigeria based on VECM approach (19602011). Prosiding Perkem, VII (1), 509-524.

Oluseyi, A. S., Olasehinde, T. J., \& Eweke, G. O. (2017). The impact of money supply onNigeria economy: A Comparison of Mixed Data Sampling (MIDAS) and ARDLApproach. Euro Economica, 2(36), 123-134.

Sahin, A., \& Dogan, I. (2017). Analysis of the neutrality of money for the US economy. Journal of Applied Sciences, 17(7), 365-373.

Singh, C., Das, R., \& Baig, J. (2015). Money, output and prices in India. Indian Institute of Management Bangalore (IIMB) working paper series. Working paper no: 497.

Siyan, P., \& Adegoriola, A. E. (2015). The relative impact of money supply and government expenditure on economic growth in Nigeria. Asian Online Journal Publishing Group. Economy, 2(3), 49-57.

Sola, O., \& Peter, A. (2013). Money supply and Inflation in Nigeria: Implications for national development. Modern Economy, 4, 161-170.

Soufan, T., \& Al Zaytoonah (2013). The causal relationship between monetary policy and economic growth in Jordan during the period 1978-2010. Interdisciplinary Journal ofContemporary Research in Business, 5(8), 56-67.

Sturgill, B. (2014). Money growth and economic growth in developed nations: An empiricalanalysis. Journal of Applied Business and Economics, 16(4), 41-52.

Tabar, F. J., Najafi, Z., \& Badooei, Y. S. (2016). The relationship between money supply, prices, government expenditure and economic growth in Iran economy. International Journal of Humanities and Cultural Studies, Special Issue; 483-495.

Tabi, H. N., \& Ondoa, H. A. (2011). Inflation, money and economic growth in Cameroon.International Journal of Financial Research, 2(1), 45-56.

Yan-liang, W. (2012). Relationship research on money supply, economic growth and inflation. Journal of Convergence Information Technology (JCIT), 7(11), 20-28. 